\title{
Can ground source heat pumps perform well in Alaska?
}

\section{Robbin Garber-Slaght}

\author{
Rorik Peterson
}

\begin{abstract}
The long heating season and cold soils of Alaska provide a harsh testing ground for ground source heat pumps (GSHPs), even those designed and marketed for colder climates. Fairbanks, Alaska has $7,509^{\circ} \mathrm{C}$ beating degree-days $s_{18}\left(13,517^{\circ} \mathrm{F} H \mathrm{HD}_{65}\right)$ and only $40^{\circ} \mathrm{C}$ cooling degree-days $18\left(72^{\circ} \mathrm{F}\right.$ $\left.C D D_{65}\right)$. This large and unbalanced heating load creates a questionable environment for GSHPs. In addition, soil temperatures average around freezing $\left(0^{\circ} \mathrm{C} / 32^{\circ} \mathrm{F}\right)$; the soil may be permafrost year-round, just above freezing, or in an annual freeze-thaw cycle. In 2013 the Cold Climate Housing Research Center (CCHRC) installed a GSHP at its facility in Fairbanks. The heat pump replaced an oil-fired condensing boiler heating a $464 m^{2}$ (5,000 ft')office space. The ground heat exchanger was installed in a marginal area underlain with permafrost near $0^{\circ} \mathrm{C}\left(32^{\circ} \mathrm{F}\right)$. The intent of the installation was to observe and monitor the system over a 10-year period in order to develop a better understanding of the performance of GSHPs in ground with permafrost and to help inform future design. The system enjoyed one season of better-than-expected performance, averaging a COP of 3.7its first winter. By the third winter, the COP had dropped to an annual average of 3.2 and ice had started to develop in the area around the heat extraction coils. A combination of physical monitoring and numerical modeling is used to evaluate the beat pump system.
\end{abstract}

\section{NTRODUCTI ON}

The Cold Climate Housing Research Center and the Alaska Center for Energy and Power (ACEP) completed a study on the state and use of GSHP technology in cold climates in 2011 (Meyer, et al.). They found that even with high capital costs of GSHPs, a ground source system with a minimum COP of 2.5 can be cost effective in several parts of Alaska. The study also found that the use of GSHPs is increasing in cold climates as the technology improves, but determined that there is a lack in long term studies in cold climates. Of particular interest is the long term effect of unbalanced heat extraction on the soil surrounding the ground heat exchanger (GHE) and the degradation in the efficiency of the heat pump system.

Wu, et al. (2013) point out that the soil temperatures around a GHE in a heating dominated climate can degrade over time, which lowers the efficiency of the GSHP. There are several approaches to address this problem: increasing the GHE size, installing a secondary heating source, and using thermal storage (Wu et al., 2013). You, et al. (2016) also suggest several ways to improve GHE performance. Increasing the size of the GHE or changing the layout of boreholes can mitigate thermal imbalance slightly, but is not effective for a larger imbalance. Modifying the heat pump system itself to include auxiliary heating sources or using the heat pump only at certain times of the day when other heating options are not available is a practical and effective way to help the heat pump maintain efficiency (You et al., 2016). 
Prior to this CCHRC study, the longest GSHP study in Alaska lasted for 1.5 years and concluded that the soil

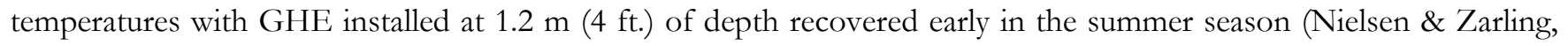
1983). A Southcentral Alaska study that lasted one year found that deeper $(2.7 \mathrm{~m}, 9 \mathrm{ft}$.) heat extraction coils did not recover temperature completely in the summer months, whereas the shallower $(1.5 \mathrm{~m}, 5 \mathrm{ft}$.) coils recovered well (Mueller \& Zarling, 1996).

Phase changes from liquid to solid in the soil have the potential to improve energy transfer and prolong the life of the GHE. Eslami-nejad \& Bernier (2012) found that by saturating soils around the GHE boreholes, energy from the freezing phase change was added to the heat pump system. Yang, et al. (2015) found that freezing in the GHE area can enhance the heat transfer performance and can help downsizing the heat exchanger.

Razaei, et al. (2012) studied the effects of surface treatments on the soil temperatures in a GHE. A layer of tire derived aggregate $0.2 \mathrm{~m}$ (0.6 ft.) deep has effects on the soil temperatures down to $4 \mathrm{~m}(13 \mathrm{ft}$.). The surface layer of aggregate had the potential to increase the energy absorbed from the GHE by $17 \%$ over no surface treatment and the aggregate performed better in cold climates.

\section{THE CCHRC HEAT PUMP}

CCHRC's Research and Testing Facility (RTF) is located on the campus of the University of Alaska Fairbanks (UAF). Fairbanks has $7,509^{\circ} \mathrm{C} \mathrm{HDD}_{18}\left(13,517^{\circ} \mathrm{F} \mathrm{HDD}_{65}\right)$ and $40^{\circ} \mathrm{C} \mathrm{CDD}_{18}\left(72^{\circ} \mathrm{F} \mathrm{CDD}_{65}\right)$; the $99.6 \%$ design temperature is $-41.9^{\circ} \mathrm{C}\left(-43.5^{\circ} \mathrm{F}\right.$ ) (ASHRAE, 2013). Fairbanks is in a zone of discontinuous and warm permafrost. The area surrounding the RTF is an open field that was cleared of native vegetation more than 60 years ago and is made up of moist silt (Shannon \& Wilson, Inc., 2002). The permafrost underlying the RTF has been degrading since the land was first cleared. In 2006, the top of the permafrost layer on the site ranged from 3 to $7.3 \mathrm{~m}$ (10 to $24 \mathrm{ft}$.).

The CCHRC RTF is $2,044 \mathrm{~m}^{2}\left(22,000 \mathrm{ft}^{2}\right)$ with 3 distinct heating sections. The heat pump was sized to heat the $464 \mathrm{~m}^{2}\left(5,000 \mathrm{ft}^{2}\right)$ office space on the east side of the building with a design heat load of $17.5 \mathrm{~kW}(60,000 \mathrm{BTU} / \mathrm{hr}$.). Heat is distributed to the office space via in-floor hydronic tubing that is embedded in concrete. The office space has 9 thermostatic controlled zone valves. The heat pump system replaced a $22.3 \mathrm{~kW}$ (76,000 BTU/hr.) oil fired condensing boiler and a wood fired masonry heater as the main source of heat for this portion of the building; the masonry heater is still used for supplemental space heating and ambiance.

The soils around the RTF have been extensively surveyed in the past 20 years for road and building construction. This survey information was used to inform the design of the GHE. Test boreholes drilled on the site in 2006 prior to the construction of the RTF found the site underlain with a sloping layer of permafrost. The top of the layer started at $3 \mathrm{~m}$ (10 ft.) on the south side of the building and sloped down to $9.1 \mathrm{~m}(30 \mathrm{ft}$.) on the north side. Data collected under the building since 2006 shows that the top of the permafrost has further degraded $0.6 \mathrm{~m}(2 \mathrm{ft}$.). A test borehole in 2012 prior to installing the ground loop did not find permafrost within $9.1 \mathrm{~m}(30 \mathrm{ft}$.) of the surface.

A soil thermal conductivity test was conducted in October 2012, one year prior to the installation of the heat pump. A $34 \mathrm{~m}$ (112 ft.) long horizontal loop at $2.7 \mathrm{~m}$ (9 ft.) of depth was installed 12 days prior to the testing. The test duration was 48 hours. The soil thermal conductivity was found to be $1.42 \mathrm{~W} / \mathrm{m} \cdot \mathrm{K}\left(0.82 \mathrm{Btu} / \mathrm{hr} \cdot \mathrm{ft} \cdot{ }^{\circ} \mathrm{F}\right)$. The thermal diffusivity was estimated to be $0.055 \mathrm{~m}^{2} /$ day $\left(0.59 \mathrm{ft}^{2} /\right.$ day $)$.

Originally, CCHRC wanted to demonstrate both deep wells and horizontally trenched GHEs. However, test bores for Thompson Drive (about $183 \mathrm{~m}$ (200 yards) from the ground loop field) construction in 2001 discovered frozen schist bedrock from $19.5 \mathrm{~m}$ (64 ft.) down to $45.7 \mathrm{~m}$ (150 ft.) (the bottom of the boreholes). The frozen schist was $-6.7^{\circ} \mathrm{C}\left(20^{\circ} \mathrm{F}\right)$, which was deemed too cold to use in this demonstration. A horizontal GHE was designed based on the technology available in Fairbanks at the time. Since directionally drilling was not an option, horizontal slinky coils were developed. Six $30.5 \mathrm{~m}$ (100 ft.) long by $1 \mathrm{~m}$ (3 ft.) wide slinky coils with an $0.5 \mathrm{~m}(18 \mathrm{in}$.) pitch were installed $1.8 \mathrm{~m}$ (6 ft.) apart (see Figure 1). Overall, 1,463 m (4,800 lineal ft.) of $1.9 \mathrm{~cm}(3 / 4 \mathrm{in})$ HDPE was installed at $2.7 \mathrm{~m}(9 \mathrm{ft}$.) depth to create the in-ground heat exchanger. The GHE size and depth were determined based on knowledge of past installations in the area, in conjunction with ground thermal conductivity test data, and information 
from the model.

The depth of the GHE is greater than recommended by the Mueller \& Zarling (1996) and Nielsen \& Zarling (1983) Alaskan studies. The depth was chosen to be below the line of seasonal frost and above the top of the permafrost. In addition, the $2.7 \mathrm{~m}$ (9 ft.) depth is the typical installation depth for residential horizontal GHE in the Fairbanks area. Part of the finite element analysis portion of this study is to determine an optimum depth for the ground heat exchanger.

In addition to determining an optimum heat exchanger depth, this study is also looking into whether different ground coverings are more advantageous for energy recharge. Three different coverings are being evaluated: dark rocks, sand, and grass. Each treatment covers 2 slinky loops (see Figure 1). The soil temperatures under the coverings are monitored as are the temperatures of the fluid returning from the coils.

The heat pump itself is a residential $21 \mathrm{~kW}$ (6 ton) water to water unit, chosen based on previous experience with the model in Fairbanks. It is connected to the existing in-floor heat delivery system. The heat pump heats a 303 liter (80 gallon) buffer tank of water to a temperature determined by outdoor air temperature. The minimum temperature for the buffer tank is $26.7^{\circ} \mathrm{C}\left(80^{\circ} \mathrm{F}\right)$ and the maximum is $42.8^{\circ} \mathrm{C}\left(109^{\circ} \mathrm{F}\right)$. The GHE side of the heat pump is charged with a $20 \%$ methanol, $80 \%$ water mixture. The building hydronic side of the heat pump is charged with water. All energy flows to and from the heat pump are monitored.

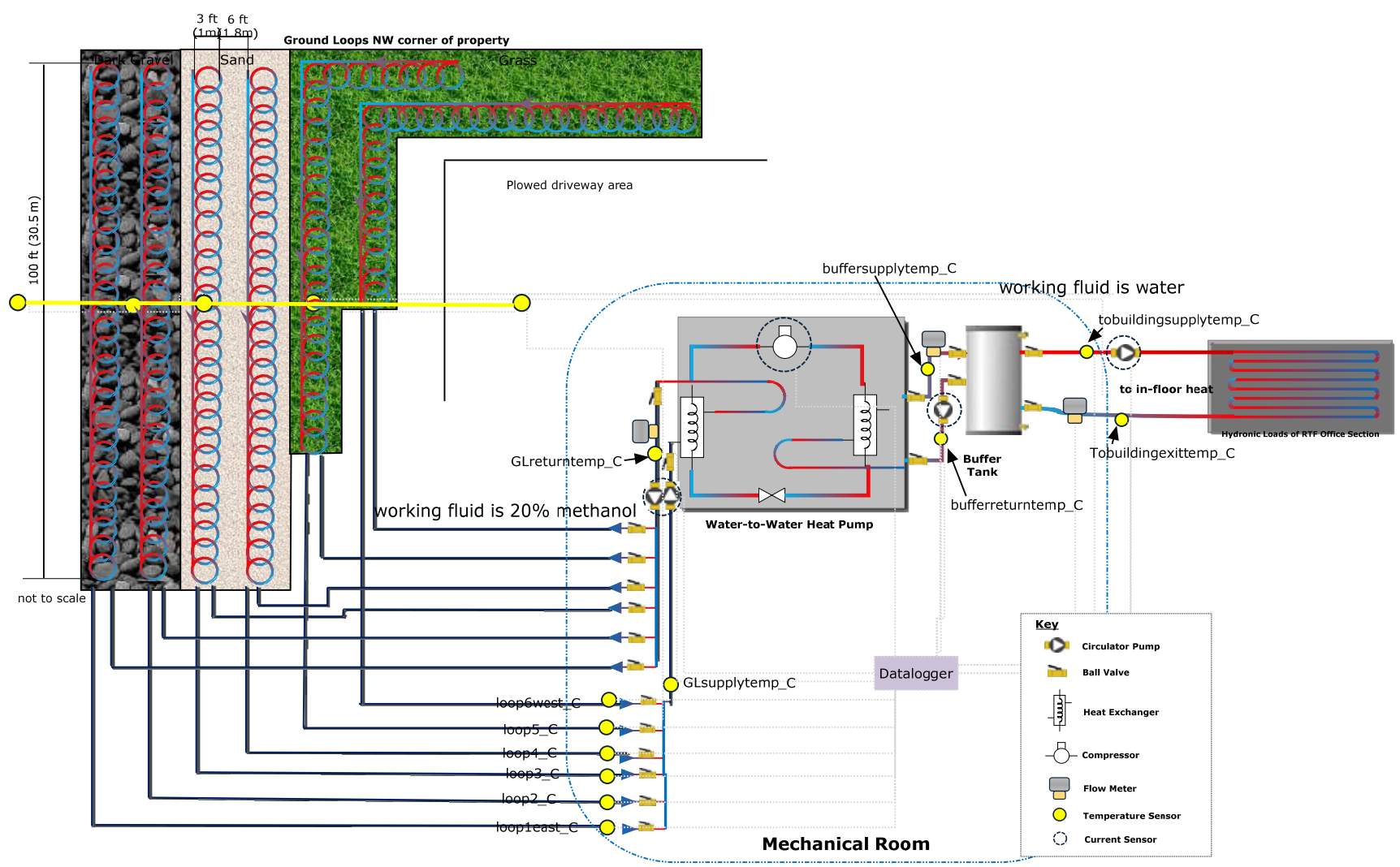

Figure 1 CCHRC's heat pump. The schematic includes the location and type of data collection sensors used in the project. The temperature sensors across the GHE also extend vertically down to create a soil temperature profile. The center vertical temperature string measures into the ground at $0.3 \mathrm{~m}, 0.6 \mathrm{~m}, 1 \mathrm{~m}, 2.1 \mathrm{~m}, 2.9 \mathrm{~m}, 3.5$ $\mathrm{m}$ and $4.1 \mathrm{~m}(1 \mathrm{ft}$., $2 \mathrm{ft}$., $3.5 \mathrm{ft}$., $7 \mathrm{ft}$., $9.5 \mathrm{ft}$., $11.5 \mathrm{ft}$., and $13.5 \mathrm{ft}$.). The other four temperature strings are spaced at $0.25 \mathrm{~m}, 0.75 \mathrm{~m}, 1 \mathrm{~m}, 1.5 \mathrm{~m}, 2 \mathrm{~m}, 2.7 \mathrm{~m}, 3.2 \mathrm{~m}$, and $3.7 \mathrm{~m}(0.8 \mathrm{ft}$., $2.5 \mathrm{ft}$., $3.3 \mathrm{ft}$., $5 \mathrm{ft}$., $6.5 \mathrm{ft}$. $9 \mathrm{ft}$., $10.5 \mathrm{ft}$., and $12 \mathrm{ft}$.). There are 50 in-ground temperature sensors in total. 


\section{CCHRC GSHP RESULTS}

Temperatures recorded in and around the GHE show a steady cooling of the ground over the three years the heat pump has been in use. The temperatures in the vicinity of the heat extraction coils are colder than the baseline temperatures in the adjacent field. The temperature at the depth of the coils shows $0^{\circ} \mathrm{C}\left(32^{\circ} \mathrm{F}\right)$ most of the winter, the baseline temperatures are 3 to $4 \mathrm{C}^{\circ}\left(5.4\right.$ to $\left.7.2 \mathrm{~F}^{\circ}\right)$ higher. The temperature has not dropped below freezing as energy of phase change is extracted from the surrounding soils, freezing the soils before the temperature drops further. Thus far the soil around the loops has risen above freezing each summer. Figure 2 shows the ground temperatures over the three years. The temperatues at the depth of the GHE $(2.7 \mathrm{~m}, 9 \mathrm{ft})$ have remained close to the freezing line since December 2015. They have not dropped much below the freezing point in three years, but could if permafrost develops in the GHE area.

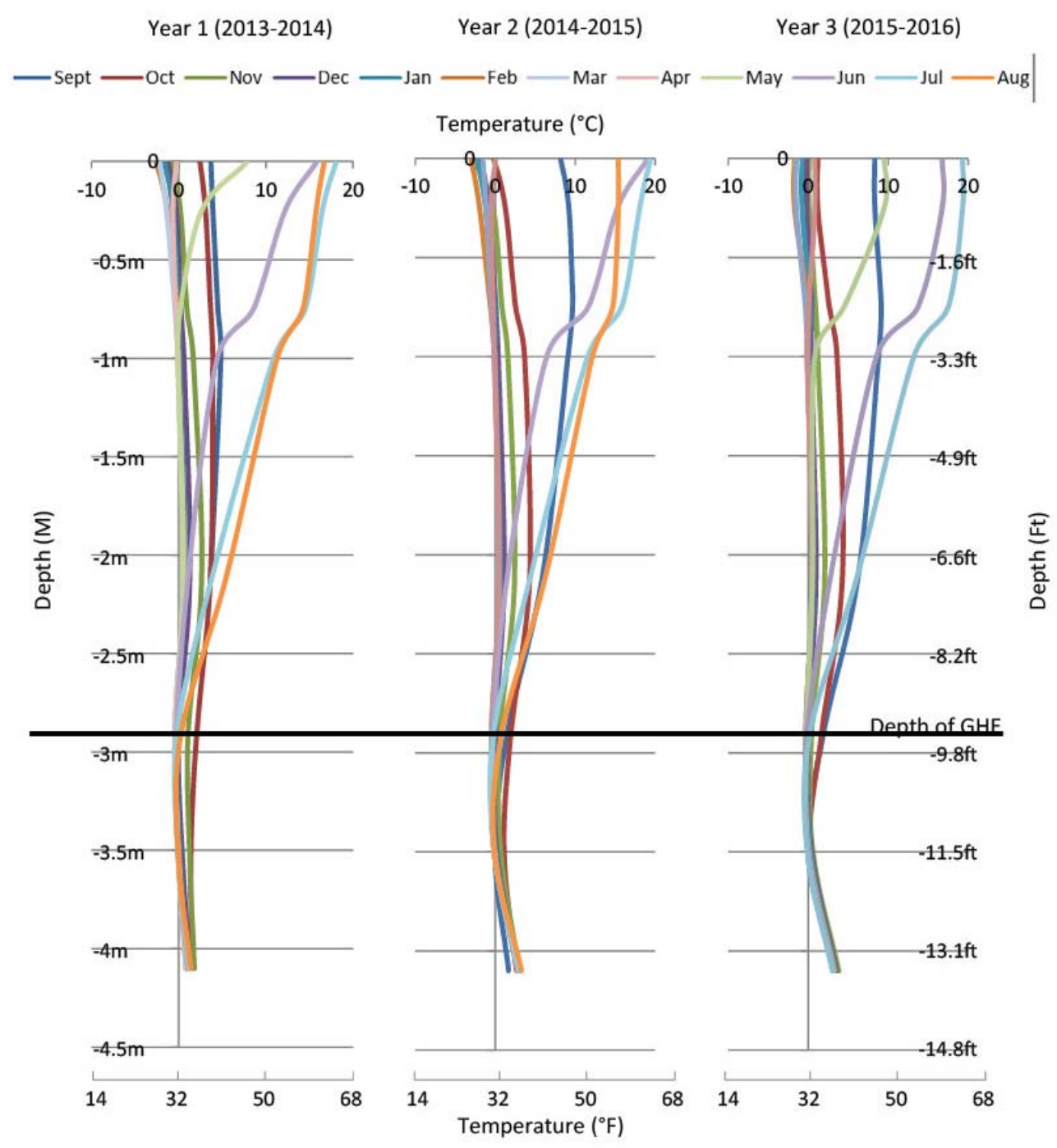

Figure 2 Whiplash curves of the center of the GHE for 3 years. Temperatures do not drop below freezing but as permanent ice develops, colder temperatures may result. Each year starts in September and ends in August. 
Permafrost. Permafrost tubes in the GHE show some ice creation within the slinky coil in the center of the GHE. The ice does not spread beyond the slinky coil, as far as can be determined from the permafrost tubes. Ice developed around the center slinky coil in February 2016 and grew to $1.4 \mathrm{~m}(4.5 \mathrm{ft}$.) of ice on, above, and below the slinky coil (there is an undetermined amount of error on the permafrost tubes). The ice had melted by July 2016.

Surface treatments. Temperatures in the GHE show the effects of the differing surface treatments. Deeper down in the GHE the effects of the surface treatments are harder to discern, especially around the slinky coils where the heat extraction has an overwhelming effect on the ground temperatures. However, the dark gravel is keeping that section of the GHE warmer than the sand or the grass. The temperatures in the manifold (Figure 3) show that the fluid returning from the gravel loops is always slightly warmer than the other two surface treatment loops. The differences in the surface treatments are noticeable in the fall of 2015 , with the gravel $0.5 \mathrm{C}^{\circ}\left(0.9 \mathrm{~F}^{\circ}\right)$ warmer than the sand loops and $1 \mathrm{C}^{\circ}\left(1.8 \mathrm{~F}^{\circ}\right)$ warmer than the grass loops. As the winter progressed the gravel loops stayed warmer than the other loops but there was less of a difference. The sand loops ended the winter season with the coldest temperatures.

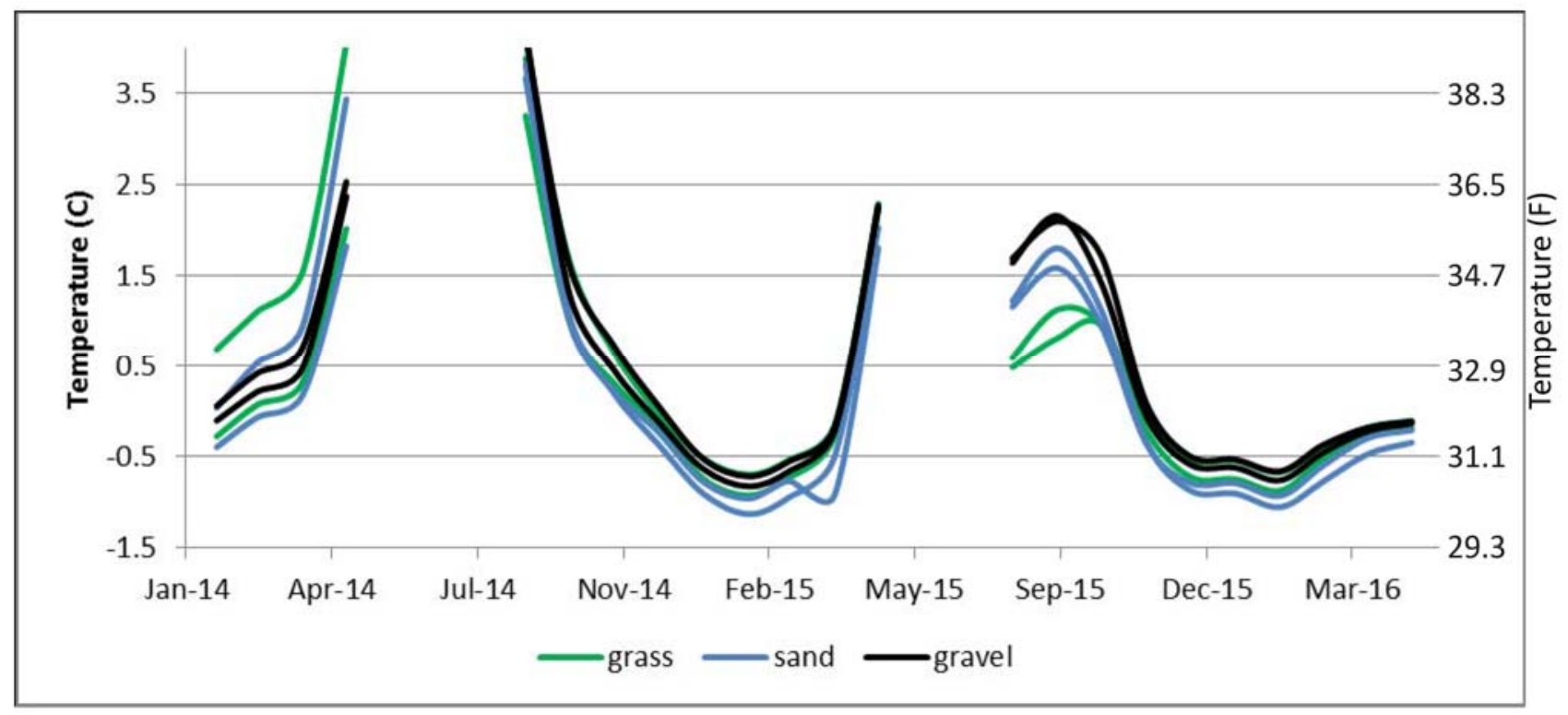

Figure 3 Temperatures of the fluid returning from the GHE. The temperatures in the beginning of 2014 do not have the effects of the summer on the surface treatments as the system was not complete until September 2013. Holes in the data are due to no fluid returning to the building. Each surface treatment has 2 coils returning to the building.

Efficiency. The efficiency of the heat pump varied over the course of each heating season. It tended to be higher in autumn when the GHE was the warmest and fell over the course of the winter. However, as the heating demand of the building lessened, the COP improved as the heat pump delivered lower temperature heat to the building. Figure 4 shows the trend for the COP. The COP for the heat pump is trending slightly lower over time, with a $14 \%$ decline in the annual average over 3 years. Although the average decline from year 2 to year 3 was less significant at $3 \%$. 


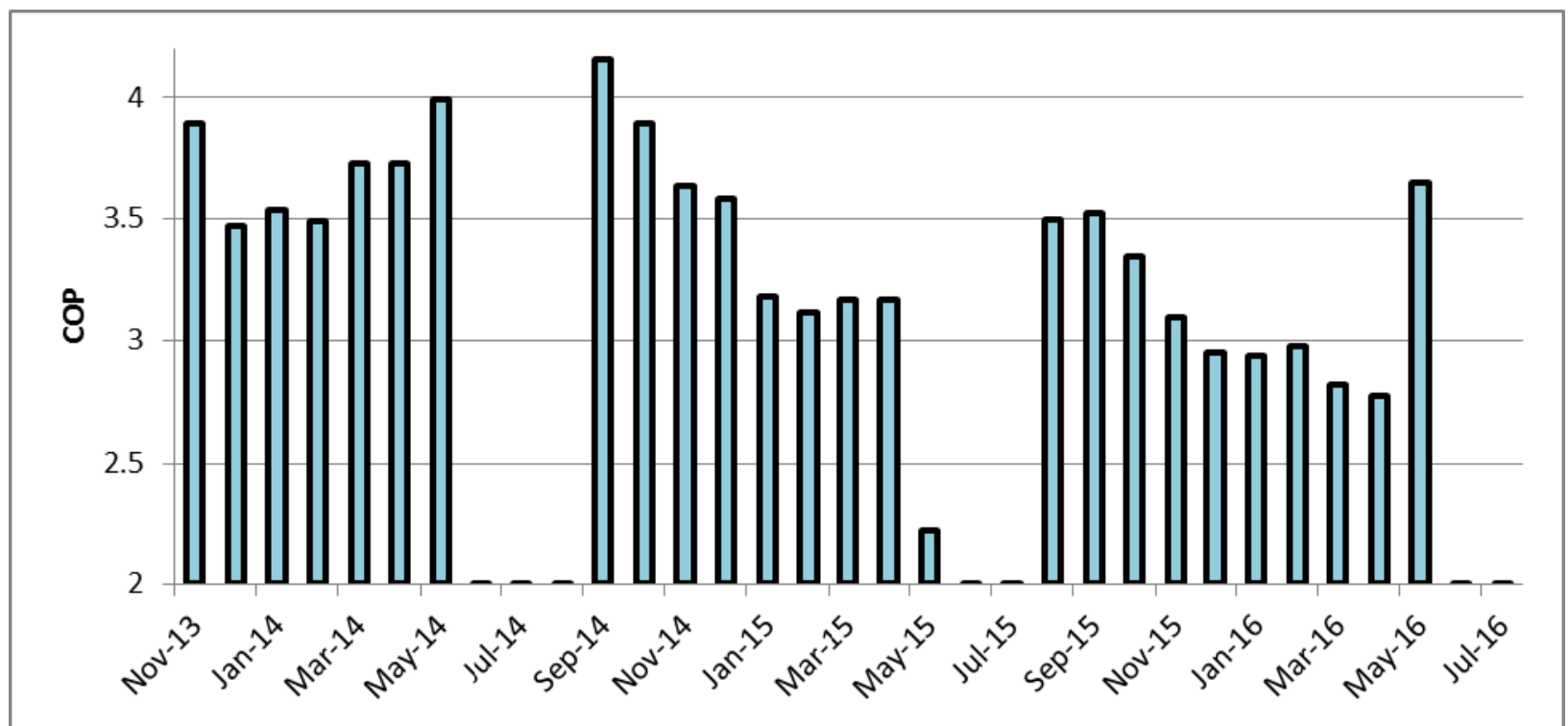

Figure 4 Heat pump COP over time. The COP calculated for May 2015 is an outlier that is not explained with the existing data, however some of the zone valves for the in-floor delivery were stuck open which could potentially explain odd data.

\section{GHE NUMERI CAL MODEL}

A numerical finite-element model was constructed to simulate the purely conductive heat transfer with water content phase change behavior of the ground soil surrounding the GHE using Comsol Multiphysics 5.2a with a PARDISO solver. Physical properties (e.g. porosity) were based on field measurements and the corresponding thermal properties (e.g. heat capacity) used Kersten correlations (Andersland and Ladanyi, 2004). Phase change behavior was numerically implemented using a pseudo-heat capacity method over a finite yet narrow temperature range immediately below $0^{\circ} \mathrm{C}\left(32^{\circ} \mathrm{F}\right)$. Model simulations were run for 10 years starting from an initial soil temperature distribution recorded just after installation. Time stepping is adaptive, and a more restrictive maximum step of 3,600 seconds was added to assure phase change behavior was not "stepped over" by the pseudo-heat capacity implementation.

Both a two- and three-dimensional models were built. The two-dimensional model was a symmetric vertical cut from the ground surface extending $30 \mathrm{~m}$ (98.4 ft.) down and $2 \mathrm{~m}(6.6 \mathrm{ft}$.) wide; with the line of symmetry directly through the center-line of the GHE. This geometry was arrived at using the three-dimensional model which indicated that the heat flux and all associated physical phenomena were primarily in the vertical direction except in the immediate vicinity of the heat-extraction coils. Here, there is some off-vertical heat that extended less than one meter horizontally. Therefore the 2 -meter wide ( $4 \mathrm{~m}$ (13.1 ft.) due to symmetry) system was able to adequately capture the thermal behavior at a substantial computational saving.

The model parameters and boundary conditions were specified to approximate the conditions at the test location as close as possible without introducing substantial and unnecessary complexity. In some instances, analytical functions were used to approximate actual conditions. For example, the air temperature at the top boundary of the model domain was modeled as a sinusoidal function of period 1 year with an amplitude, phase offset, plus a constant component to match the climatic average at the testing location. The heat pump thermal demand (from the ground) was modeled by approximating a truncated sinusoidal function with zero demand in the warmer months and was based on the actual heat supplied to the building in year 2 of the study. The same profiles were used for each year of 
the 10-year simulations. A sensitivity analysis of building demand (e.g. temperature) was not completed.

\section{NUMERI CAL MODEL RESULTS}

Figure 5 shows the modeled temperature at several depths (in meters) over the initial 3 year period of the simulations (from the 2-D model at the center of the GHE). The depths closely approximate the temperature sensor depth locations in the field study to within $5 \mathrm{~cm}$. There is a gradual decline in temperature near the heat pump energy extraction depth $(2.7 \mathrm{~m}, 9 \mathrm{ft}$.), with more consistent periodic temperatures at the shallower and deeper depths. This repeatability from year to year is due to the fact that the same air temperature profile (climatic average) was used for each year of the simulation. The simulated temperatures at depth agree fairly well with the recorded temperatures (the annual average is within $0.09^{\circ} \mathrm{C}\left(0.16^{\circ} \mathrm{F}\right)$ at $3.5 \mathrm{~m}(11.5 \mathrm{ft}$. $)$ and $0.23^{\circ} \mathrm{C}\left(0.41^{\circ} \mathrm{F}\right)$ at $2.9 \mathrm{~m}(9.5 \mathrm{ft}$. $)$ in the third year of the model and study) considering the approximations of the heat demand and surface boundary conditions. Model simulations were run for 10 years, and stabilization was generally observed after 5 years as the longer-term modeled temperatures shown in Figure 5 indicate.

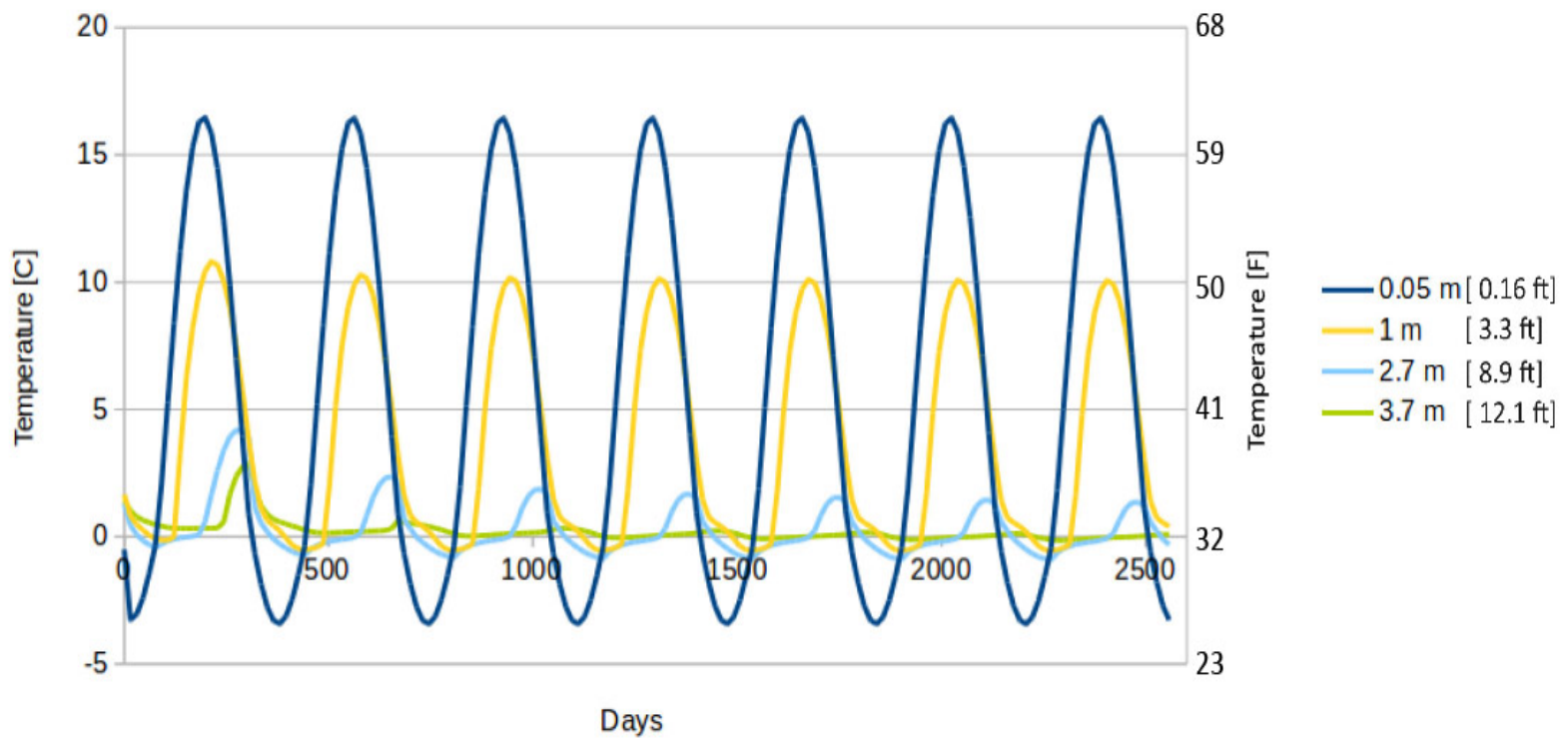

Figure 5 Modeled temperature over time. Days start in January and run out for seven years. The depth slightly above the GHE coils at $2.7 \mathrm{~m}$ (9 ft.) shows a slight below-freezing temperature at its coldest; around $-1^{\circ} \mathrm{C}\left(30.2^{\circ} \mathrm{F}\right)$, while the actual data recorded are around $0^{\circ} \mathrm{C}\left(32^{\circ} \mathrm{F}\right)$ indicating the soil is at the freezing point. The simulation causes the model to indicate slightly below freezing temperatures during phase change; any temperature around 0 to$1^{\circ} \mathrm{C}$ indicates phase change.

The heat pump COP varies as a function of the heat absorption reservoir temperature, and the equipment manual provides this performance information for temperatures from $-7^{\circ} \mathrm{C}$ to $21^{\circ} \mathrm{C}\left(20^{\circ} \mathrm{F}\right.$ to $\left.70^{\circ} \mathrm{F}\right)$. In order to simulate the varying performance as the ground temperature varied throughout the simulation, a least-squares linear fit to the performance data was obtained. This was then used to specify the expected COP. Actual recorded COP values were slightly higher than those predicted by the simulation, and may be due to several different factors such as the building heat supply temperature. The performance data used for the model was based on an assumed constant building supply temperature of $38^{\circ} \mathrm{C}\left(100^{\circ} \mathrm{F}\right)$.

To assess the expected performance of the heat pump if the GHE had been installed at a different depth, the heat 
removal term in the model (the depth of the GHE coils) was placed at different depths in the model domain. Depths ranging from 1 to $4 \mathrm{~m}$ ( 3.3 to $13 \mathrm{ft}$.) (every $0.5 \mathrm{~m}, 1.6 \mathrm{ft}$.) were examined. Figure 6 shows the yearly average expected COP of the heat pump system if the GHE coils had been installed at these depths. The simulations indicate that deeper depths result in higher COP, with a diminishing return after 2 to $2.5 \mathrm{~m}$ (6.6 to $8 \mathrm{ft}$.). The performance at all depths stabilizes after about 5 years. It is interesting to note that the shallowest depth $(1 \mathrm{~m}, 3.3 \mathrm{ft}$.) has slightly higher average COP than $1.5 \mathrm{~m}$ (4.9 ft.) after 10 years (although both depths have significantly low COP values). This is likely due to some small amount of passive surface energy recharge during the warmer summer months. Although this effect is small, the implication seems to be that surface energy recharge is not significant in the natural state at depths below around 1 meter, regardless of the three different surface treatments. Active recharge is required at depths below around 1 meter in order to get the natural heat to penetrate to those depths, such as reverse operation of the GHE coils, or a separate heating system such as a solar-thermal system.

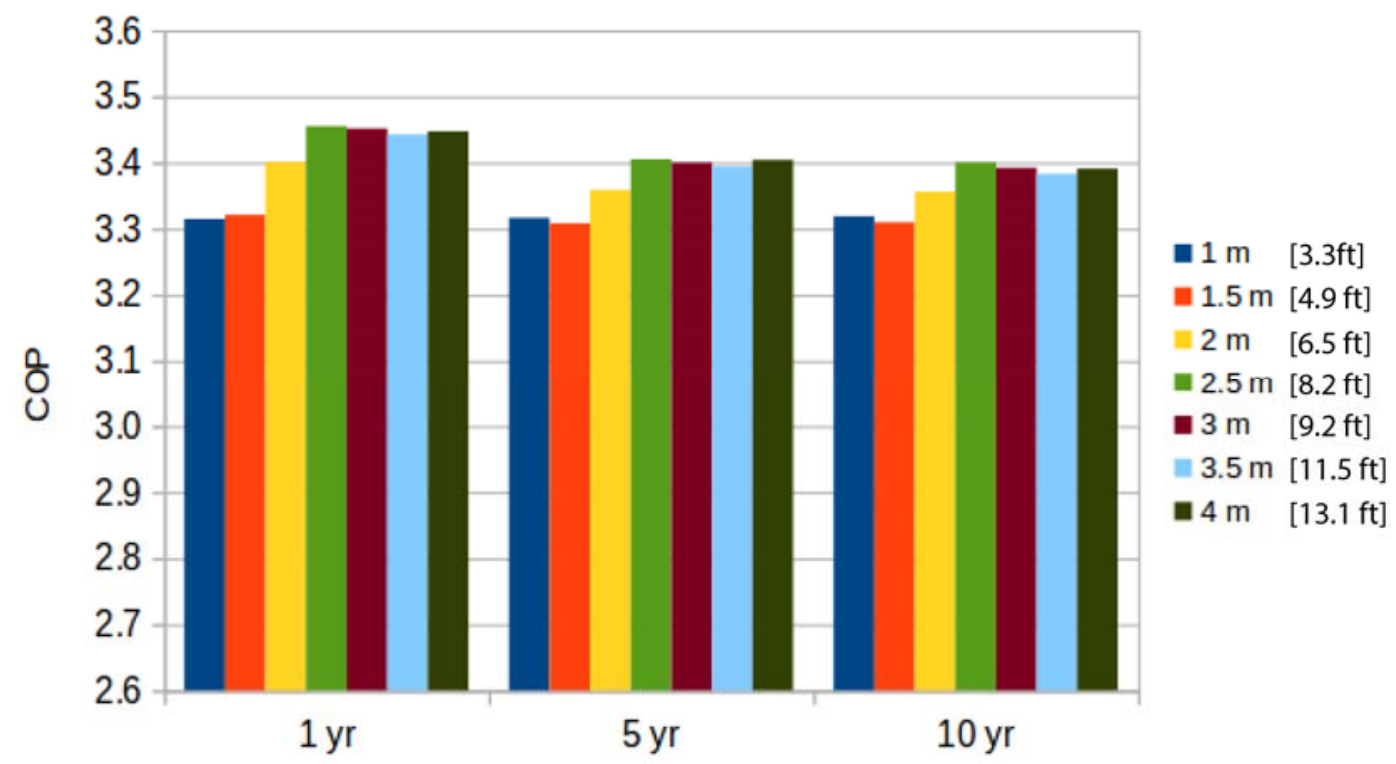

Figure 6 Modeled annual COP. Each bar represents a different depth of the GHE coils from the surface.

\section{CONCLUSI ONS}

Data from the first 3 years of heat pump operation show a 14\% decline in COP; however the drop in COP is only $3 \%$ from year 2 to year 3 , potentially indicating stabilization in the near future. The numerical modeling suggests that the decline will level out around year 5, and that the COP will not be much lower than 3.4. The original ACEP/CCHRC study found that a GSHP with a COP of 2.5 or greater would be cost effective in Fairbanks (Meyer et al., 2011). Three years of operation is certainly not long enough to see all the changes the heat pump will create in the soil thermal regime. This heat pump demonstration will be monitored for at least another 7 years to verify the degradation in the soil temperatures and the COP. If the loss in efficiency becomes too burdensome to the cost to operate the heat pump, methods to bring the ground loop into better thermal balance may be instituted.

\section{ACKNOWLEDGMENTS}

This project was funded with an Emerging Energy Technology Fund Grant via the Alaska Energy Authority and the Denali Commission. Further funding was supplied by the Alaska Housing Finance Corporation. Special thanks to Alaska Geothermal LLC and GRTI for donating time and equipment. 


\section{REFERENCES}

Andersland, O. \& Ladanyi, B. 2004. Frozen ground engineering. John Wiley \& Sons.

ASHRAE. 2013. ASHRAE Handbook-Fundamentals. Atlanta: American Society of Heating Refrigeration and Air Conditioning Engineers, Inc.

Eslami-nejad, P. \& Bernier, M. 2012. Freezing of geothermal borehole surrounding: a numerical and experimental assessment with applications. Applied Energy 98: 333-345.

Meyer, J., Pride, D., O’Toole, J., Craven, C,. \& Spencer, V. 2011. Ground source heat pumps in cold climates. Avaliable online at: http://cchrc.org/docs/reports/Ground-Source-Heat-Pumps-in-Cold-Climates.pdf

Mueller, G. \& Zarling, J. 1996. Ground source heat pump monitoring: final report. Matanuska Electric Association. Alaska.

Nielsen, H. \& Zarling, J. 1983. Ground source heat pump demonstration. University of Alaska, Fairbanks. Fairbanks, AK.

Rezaei, A., Kolahdouz, E., Dargush, G., \& Weber, S. 2012. Ground source heat pump pipe performance with tire derived aggregate. International Journal of Heat and Mass Transfer 55: 2844-2853.

Shannon \& Wilson, Inc. 2002. Geotechnical design review, proposed UAF/New Geist Road access Fairbanks, Alaska. Submitted to Alaska Department of Transportation and Public Facilities.

Wu, W., Wang, B., You, T., Shi, W., \& Li, Z. 2013. A potential solution for thermal imbalance of ground source heat pump systems in cold regions: ground source absorption heat pump. Renewable Energy 59: 39-48.

Yang, W., Kong, L., \& Chen, Y. 2015. Numerical evaluation on the effects of soil freezing on underground temperature variation of soil around ground heat exchangers. Applied Thermal Engineering 75: 259-269.

You, T., Wu, W., Shi, W., Wang, B., \& Li, X. 2016. An overview of the problems and solutions of soil thermal imbalance of groundcoupled heat pumps in cold regions. Applied Energy 177: 515-536. 